\title{
Margaret McCartney: The private sector providers letting down the NHS
}

\author{
Margaret McCartney general practitioner, Glasgow
}

Vanguard Healthcare is a private company that the NHS contracted to provide 400 cataract operations in Taunton in 2014. However, the contract was terminated after four days of operations. The trust said that 31 of 62 patients had had a complication, but it did not disclose the severity. Overall, about $2 \%$ of cataract operations are expected to have a serious complication ${ }^{1}$ - and compensation is being sought, but would it be the NHS or Vanguard that pays? ${ }^{2}$

In Cornwall, Serco pulled out early from its contract to provide out-of-hours GP care, ${ }^{3}$ after a report by the Public Accounts Committee made claims of bullying, short staffing, and alteration of performance data. ${ }^{4}$

Atos Healthcare bailed out three years into a 10 year contract of providing general practice services in Tower Hamlets, London, where it had not delivered improvements, especially around access. ${ }^{5}$

Private companies on "take or pay" contracts from the NHS - that is, where the fee is paid regardless of whether services are used - are reported to have received more than $£ 217 \mathrm{~m}$ for operations that did not happen. ${ }^{6}$ The NHS paid Clinicenta $£ 53 \mathrm{~m}$ after terminating its contract when it was found non-compliant with Care Quality Commission standards and local GPs became reluctant to refer their patients to it. ${ }^{7}$

This mess is bad for everyone. Patients are harmed through poor quality surgery, and short term contracts mean that they lose out on continuity of care. The NHS pays repeatedly: in the process of tendering out contracts; in poor value for money; and in further necessary care for patients who have had poor service from the private provider.

The lie is that the private sector can do the same jobs as the NHS more efficiently, making a profit in the process. Yet the private sector's repeated failures never seem to lead to political caution. And the private sector is not subject to the same requirements as the NHS in terms of reporting patient safety incidents or mortality data. ${ }^{8}$

A cool $£ 5.8$ bn worth of NHS work is now advertised to the private sector, ${ }^{9}$ up 14\% from last year. And NHS England has said that all new general practice contracts will be considered case by case as to whether they should be opened to bidding from the private sector. ${ }^{10}$

Our NHS is not perfect, but what benefit does privatisation bring? We can afford an evidence based, compassionate NHS; we cannot afford an NHS fuelled by political rhetoric that wastes clinical time and money.

Competing interests: I have read and understood the BMJ policy on declaration of interests and declare the following interests: I'm an NHS GP partner, with income partly dependent on Quality and Outcomes Framework (QOF) points. I'm a part time undergraduate tutor at the University of Glasgow. I've written a book and earned from broadcast and written freelance journalism. I'm an unpaid patron of Healthwatch. I make a monthly donation to Keep Our NHS Public. I'm a member of Medact. I'm occasionally paid for time, travel, and accommodation to give talks or have locum fees paid to allow me to give talks but never for any drug or public relations company. I was elected to the national council of the Royal College of General Practitioners in 2013.

Provenance and peer review: Commissioned; not externally peer reviewed.

Follow Margaret McCartney on Twitter, @mgtmccartney

Royal College of Ophthalmologists. Complications of cataract surgery. www.rcophth.ac. uk/revalidation/page.asp?section=754\&sectionTitle=Complications+of+cataract+surgery 2 Morris S. NHS faces legal bill as dozens suffer problems after eye operations. Guardian 14 August 2014. www.theguardian.com/society/2014/aug/14/nhs-eye-operations-privateprovider-musgrove.

3 Wise J. Serco pulls out of out-of-hours care in Cornwall. BMJ 2013;347:77549.

4 Public Accounts Committee. Report on out-of-hours GP service in Cornwall. 14 June 2013. www.parliament.uk/business/committees/committees-a-z/commons-select/publicaccounts-committee/news/out-of-hours-gp-service-in-cornwall/.

5 lacobucci G. Local GPs drafted in to run APMS practice after private company fails to improve access. Pulse 18 April 2011. www.pulsetoday.co.uk/local-gps-drafted-in-to-runapms-practice-after-private-company-fails-to-improve-access/12199065.article\#.VAN2R IdU41.

6 Payne D. NHS paid private sector $£ 217 \mathrm{~m}$ for operations that never took place. BMJ 2011;342:d3277.

7 Mahony C. Acute trust takes over treatment centre after £53m pay off to private company. BMJ 2013;347:44955

8 Centre for Health and the Public Interest. Patient safety in private hospitals-the known and the unknown risks. August 2014. http://chpi.org.uk/wp-content/uploads/2014/08/CHPIPatientSafety-Aug2014.pdf.

9 Plimmer G, Neville S. £5.8bn of NHS work being advertised to the private sector. Financial Times 29 July 2014. www.ft.com/cms/s/0/acbd7be4-165c-11e4-8210-00144feabdc0.html\# axzz3BgYAKK45.

10 Matthews-King A. Revealed: all new GP contracts will be open to private providers. Pulse 18 August 2014. http://bit.ly/1wDqjxJ. 
